\title{
A structural-relational analysis of party dynamics in proxy wars
}

Article

Accepted Version

Rauta, V. (2018) A structural-relational analysis of party dynamics in proxy wars. International Relations, 32 (4). pp. 449-467. ISSN 1741-2862 doi:

https://doi.org/10.1177/0047117818802436 Available at https://centaur.reading.ac.uk/79835/

It is advisable to refer to the publisher's version if you intend to cite from the work. See Guidance on citing.

To link to this article DOI: http://dx.doi.org/10.1177/0047117818802436

Publisher: Sage

All outputs in CentAUR are protected by Intellectual Property Rights law, including copyright law. Copyright and IPR is retained by the creators or other copyright holders. Terms and conditions for use of this material are defined in the End User Agreement.

\section{www.reading.ac.uk/centaur}

\section{CentAUR}

Central Archive at the University of Reading

Reading's research outputs online 


\title{
A Structural-Relational Analysis of Party Dynamics in Proxy Wars
}

\author{
Abstract
}

Proxy wars are still under-represented in conflict research and a key cause for this is the lack of conceptual and terminological care. This article seeks to demonstrate that minimizing terminological diffusion increases overall analytical stability by maximising conceptual rigor. The argument opens with a discussion on the terminological ambivalence resulting from the haphazard employment of labels referencing the parties involved in proxy wars. Here, the article introduces an analytical framework with a two-fold aim: to reduce label heterogeneity, and to argue in favour of understanding proxy war dynamics as overlapping dyads between a Beneficiary, a Proxy, and a Target. This is then applied to the issues of defining and theorising party dynamics in proxy wars. It does so by providing a structural-relational analysis of the interactions between the above-mentioned parties based on strategic interaction. It presents a tentative explanation of the proxy relationship by correlating the Beneficiary's goal towards the Target with the Proxy's preference for the Beneficiary. In adding the goal-preference relational heuristic, the article advances the recent focus on strategic interaction with a novel variant to explanations based on interest, power, cost-benefit considerations, or ideology. 
Keywords: proxy war, external support, conceptual analysis, strategic interaction, terminology

\section{Introduction}

Conceptual debates stand to correct theoretical and methodological ambivalences across a wide range of sub-fields in international relations. Often disregarded as metatheoretical trivia ${ }^{1}$, concept analyses focus on the perils of operating with notions with unclear boundaries, conflicting meanings, and divergent empirical referents. Their aims are straightforward: attaining clarity, ensuring precision, and building stable conceptual standing(s). Security ${ }^{2}$, terrorism ${ }^{3}$, and war $^{4}$ are a small sample of terms subjected to conceptual scrutiny in the discipline of international relations. Nevertheless, even established research clusters, such as that addressing civil war, still use concepts inconsistently and imperfectly ${ }^{5}$. Given the nascent state of proxy wars research, it comes as no surprise that such discussions are almost entirely absent, despite having important consequences to our understanding of the topic, chiefly of which their effect on knowledge cumulation $^{6}$.

As recently noted by Brown, 'the issue of proxy warfare has again been rising up the international agenda". Notwithstanding the erroneous overlap between proxy warfare and proxy war $^{8}$, Brown highlights the growing interest in the topic ${ }^{9}$. As the gap in the 
knowledge of proxy wars slowly narrows, it is striking to note, however, that this cluster of research is still at a critical, pre-theoretical stage. For example, attempts at theoretical examinations of causal dynamics in proxy wars are rather scarce. On the one hand, Salehyan, Gleditsch, and Cunningham put forward a theory of external support hinging on principal-agent assumptions and a demand-supply logic ${ }^{10}$. On the other, San-Akca developed a strategic interaction model involving two simultaneous selection pathways: from the state towards the non-state actor, and from the non-state actor towards the state ${ }^{11}$. These are complemented by country- or region-focused research which reveals interesting, albeit partial, insights into why proxy wars are waged ${ }^{12}$. However, no overarching theory has emerged, and the existing models complement, rather than integrate each other.

This article argues that a first step in overcoming this issue is a joint terminologicalconceptual exploration of the term 'proxy war'. Essentially, the article focuses on conceptual assessment as constitutive of the theoretical micro-foundations of proxy war research. However, for proxy wars, this is not as straightforward, for conceptual inquiry requires a deconstruction of the meaning of proxy wars as acts of violence taking the form of indirect intervention. As Mumford put it, proxy wars are indirect third-party engagements in conflicts aimed at influencing strategic outcomes. They are constitutive of 'a relationship between a benefactor, who is a state or non-state actor external to the dynamic of an existing conflict, and their chosen proxies who are the conduit for weapons, training and funding from the benefactor ${ }^{13}$. From a conceptual point of view, this implies ordering meaning 
across the complex interactions resulting between the party requiring indirect intervention, the party carrying it out, and the actual target of indirect intervention.

Nevertheless, it is at this level that research has produced a theoretically misleading terminological diffusion. Specifically, the three parties engaged in proxy wars display extraordinary label variance that not only presents limited substantive utility but adds unnecessary polemic to an already contentious topic. In the literature, the use of labels has followed the path of adapting terminology into 'novel' conceptualisations of proxy wars: choices over pairs of labels, for example, 'patron' - 'client' or 'benefactor' - 'pawn', are usually deemed semantically sufficient to mark conceptual innovation. This is a significant issue and the argument the article makes is simple, yet relevant: by minimising and reducing the semantically crowded field of labels ascribed to the parties involved in proxy wars, we develop a more stable and easily definable concept, allowing it to maximise both academic and policy tract.

An emphasis on the semantics surrounding the notion of 'proxy war' matters because we are still 'conceptually under-equipped to grasp, let alone counter, violent political challenges. ${ }^{14}$ By questioning the language we use to assess proxy wars, this article firstly taps into the recent turn towards conceptual analyses of violence-related phenomena. For example, the study of counterinsurgency has been subject to conceptual reassessment. On the one hand, there have been attempts to apply a unifying conceptual approach to counterinsurgency under the rubric of 'violent politics' that would link strategies to shifts in 
warfare. ${ }^{1.5}$ On the other, the increasing reliance on delegative strategies - military, political, operational, technological - led Waldman to introduce the notion of 'vicarious warfare'. ${ }^{16}$ Second, a focus on semantics matters because language, as Fierke put it, has a central role in how we analyse and communicate about the world. ${ }^{17}$ It is through language that one selects not just a name for the observed phenomenon, but where it starts and ends, as well as how one understands and explains it. ${ }^{18}$ More importantly, as names, labels, or terminologies are assigned to phenomena a series of normative, epistemological, and ontological associations are attached to the named subject. ${ }^{19}$ Yet, these concerns are usually ignored either because they are buried within methodological/theoretical predilections or because the concept itself is seen as largely self-evident. 'Proxy war' is far from being a selfevident concept and attaining some form of conceptual and terminological determinacy is crucial to moving the debate forward.

Finally, a focus on the terminology-concept links offers a window into smoother practitioner cooperation. No matter how specialised a concept is, it manages to permeate the public and popular discourse $\mathrm{e}^{20}$, and this is evident about proxy wars. In his last news conference, former United States President, Barak Obama, heavily criticised Russian proxy aggression $^{21}$. His Vice-President, Joe Biden, questioned the future of America's Middle Eastern alliances, arguing that historically stable allies have transformed the Syrian civil war into a proxy Sunni-Shia war ${ }^{22}$. As 'proxy war' gains discursive tract it is our task as researchers to provide policymakers with the necessary vocabulary to have an informed 
debate. ${ }^{23}$ This effort rests on clear concepts, and any degree of clarity is reached though language. Nathan Canestaro's argument provided a critique of the academic-practitioner dialogue regarding civil war definition ${ }^{24}$, and the key conclusion was that policymakers are most concerned with labelling and with the implications of politically loaded terms. In her memoirs, former US Secretary of State, Hillary Clinton, recalls the decisive role of language in reaching a diplomatic agreement over potential ceasefires in Syria with Russia: 'It's easy to get lost in the semantics, but words, [...], shaped how the rest of the world received our agreement and how it was understood on the ground in Syria ${ }^{25}$. As such, the aims of the article tackle a crucial problem which affects how proxy wars are defined, operationalised, and theorised, and, subsequently, research's ability to become policy relevant.

The article is developed across two sections whose empirical background is offered by the contemporary spread of proxy wars across the Middle East. Notwithstanding the forceful direct Russian military intervention in Syria, events in the region show how a wide range of actors now find themselves benefitting from the strategic utility of proxies. The scale of the problem was remarked by US President, Barak Obama, who explained his reluctance to act in Syria by employing the same variance in labels that informs the article's puzzle:

'[you had] a military superpower in Russia prepared to do whatever it took to keep its client-state involved, and [you had] a regional military power in Iran that saw their own vital strategic interests at 
stake and were willing to send in as many of their people or proxies to support the regime [emphasis added]. ${ }^{96}$

The first section presents a terminological assessment designed to reduce heterogeneity of labels by identifying problems resulting from their interchangeable use. It introduces the analytical framework and then attempts a corrective measure by building a case for the employment of a connotative-free set of labels: Beneficiary, Proxy, and Target. The second part of the article demonstrates the utility of minimizing terminological reach on overall conceptual rigor. The article relocates the definition of the term 'proxy war' on a strategic interaction footing by providing a structural-relational analysis of the dynamics between the abovementioned parties. It explains this relationship as the strategic correlation between the Beneficiary's goal in relation to the Target and the Proxy's preference for the Beneficiary. By introducing the goal-preference heuristic, the article pushes the debate further by allowing a closer analysis of strategic behaviour from a different angle. Simply put, while San-Acka presents a selection model between supporter and supported, I propose one in which the choice of proxy is dependent on the target, and the willingness of the proxy to accept delegation of violence is formulated by its preference, or lack thereof, for its supporter. This presents the essence of the phenomenon as a process resulting from complex, relational, and politico-strategic interaction as opposed to one based on interest, power, cost-benefit considerations, or ideology.

Minimizing Terminological Reach 
To begin with, it is important to note that proxy wars have been studied across several research clusters dealing directly or indirectly with the topic: Cold War historiography $^{27}$, intelligence studies ${ }^{28}$, and the emerging research on external support and proxy wars ${ }^{29}$. The latter now also includes research on external support and its effects on group cohesion and performance ${ }^{30}$, the role of proxy actors in electoral violence ${ }^{31}$, and war termination. $^{32}$ Adding to this is the study of proxy actors as key operatives of military purges ${ }^{33}$ and wartime sexual violence ${ }^{34}$, and, finally, as swapping roles and functions with (other) nonstate actors, most notably, militias ${ }^{35}$. Taken together, these mark a much-needed progression in our understanding of the phenomena of war by proxy, hitherto classed as understudied $^{36}$.

However, this cross-cluster dissemination is relevant to the terminological and conceptual problem discussed here because it points to its endogenous nature. Do different foci require and, therefore, produce different conceptual alternatives for the parties engaged in proxy wars? Or does conceptual plurality in fact inhibit unified scholarly debate? Endogeneity appears then, not only to simply preclude this analysis, but to also be an intrinsic part of it. In doing so, it can simultaneously deter conceptual analysis by offering the easy way out of calling 'proxy war' an essentially contested concept ${ }^{37}$, or it can become a matter of puzzlement. Against this background, I treat terminological pluralism and its 
effects on conceptual rigor as a curious quandary by reflecting only on the literatures dealing with external support and proxy wars.

In proxy war research, terminology does not concern the label for the phenomenon itself, but those applicable to the parties involved in proxy wars: the party requiring indirect intervention, the party providing indirect intervention, and the party acted upon through indirect intervention. This interplay of actors is, in fact, consistently represented in the literature. Like Mumford's definition, Hughes conceptualises proxy wars as an arrangement where a party 'helps' a third one, 'particularly if the latter is fighting an adversarial power (or target) ${ }^{38}$. Salehyan argues a similar point and presents proxy war dynamics as an example of security delegation 'where a principal (the patron state) empowers an agent (the rebel group) to carry out some foreign policy objective ${ }^{39}$. Other understandings of proxy wars rest on the same assumption ${ }^{40}$. For example, Lamb defines proxy wars as the provision of external support to a warring party ${ }^{41}$. This allows Lamb to explain proxy wars as a relationship of 'collusion between the patron and the proxy', where 'collusion' is used to capture the covert and interest-based nature of the proxy relationship ${ }^{42}$. Recently, Staniland developed the concept of 'collusion' to frame 'cooperation between state and militia in pursuit of shared interests ${ }^{43}$.

Nevertheless, what is inconsistent in the literature, and can be easily noted above, is the terminology employed in relation to each of the three parties. First, the party requesting indirect military intervention has been referred to as 'activator" ${ }^{\text {'4 }}$, benefactor ${ }^{45}$, 
'patron'46, 'principal ${ }^{47}$, 'superpower-patron' ${ }^{48}$, and 'sponsor" ${ }^{19}$. Second, the party providing the indirect military intervention has been label as 'client ${ }^{50}$, 'pawn' ${ }^{51}$, 'proxy ${ }^{92}$, 'pseudovolunteers $^{{ }^{53}}$, 'puppet ${ }^{5^{54}}$, 'satellite ${ }^{5_{5}}$; 'subordinate ${ }^{56}$; 'surrogate ${ }^{{ }^{57}}$, 'superclient ${ }^{58}$, 'tool ${ }^{59}$, and 'volunteer ${ }^{60}$. Third, the party being acted upon through indirect intervention has been called 'adversary ${ }^{91}$, 'opposition" ${ }^{92}$, and 'target ${ }^{93}$.

This section of the article challenges the need for this excessive heterogeneity of labels arguing that terminological shifts affect the overall meaning of 'proxy war' by assigning meaning and value ex ante. This problem underscores the importance of this discussion on the semantics surrounding proxy wars because the employment of such a terminological roster assigns plural ontological and epistemological meanings to the overall concept. This section seeks to establish an optimal use of labels that minimizes the terminological reach and sets the basis for achieving stronger conceptual rigor. It introduces a framework aimed at determining a pairing of labels that speak to what the literature has agreed is a stable set of properties of proxy wars - third party, indirect intervention - while underlying the interactive and mutually constitutive nature of relationship. The framework includes two criteria: normative endorsement, and relational enforcement. I classify the first one in 'low' and 'high' categories, and the second into 'positive' and 'negative', operationalization explained below.

In political science, normative benchmarks and choices over theoretical schools or frameworks have significant bearing on the phenomena to which they are applied. The 
criterion of endorsement explores the links between 'proxy war' and the usual tendency to normatively embed the phenomenon in the ideological fabric of the Cold War. Bar-Siman Tov's terminological choices make a case in point: the Activator-Proxy relationship is an expression of power which ultimately allows the achievement of the Activator's strategic goals and political interests at a lower level of risk, irrespective of the role and position of the $\operatorname{proxy}^{64}$. This has become a standard depiction of a proxy, and some of the earliest analyses of the Syrian proxy wars drew immediate comparisons to superpower adventurism in the Third World, claiming that the American-Russian approach to Syria was of Cold War essence ${ }^{65}$. This is a problem because it positions an incompatibility in a faulty theoretical framework without any discussion of either party's goals. More importantly, it falls victim to the same unwarranted politicisation of explanations which the article presented as rationale for the need of semantic analysis.

As a classificatory criterion, endorsement is rooted in Freeden's notions of 'ideological morphology' and 'thought edifices' which reference a concept's frame of political conduct and action by linking word and meaning 'with a particular conception of human nature, a particular conception of social structure, of justice, of liberty, of authority ${ }^{96}$. I focus on ideological normativity because of an existing bias in proxy wars research towards presenting the term as ideologically confined to superpower rivalry. Because of the long history of proxy wars during the Cold War, research has tended to reject ex ante the potential ability of the concept of 'proxy wars' to capture the realities of twenty-first century 
violence $^{67}$. This complaint is also made by Tamm $^{68}$ and San-Akca ${ }^{69}$ in whose understanding, 'proxy war' seems to be supra-rationalised by the Cold War ideological struggle as a 'virtual freeze-frame ${ }^{7_{0}}$. Because of this, assessing label accuracy through the lens of its normative prescriptiveness helps determine conceptual clarity outside the West-East Cold War framework. By reflecting on normativity, the framework filters labels by presenting an accurately contextualised concept useful for both research and policy.

Complementing the evaluation of normative prescription, is the second criterion: existence or absence of control levels between the supporting and receiving parties. Endorsement is matched by enforcement, understood as the ability of a label to imply negative or positive enforcement of control in the proxy war relationship: negative implying total subordination, positive marking a cooperative relationship along the lines of collusion $^{71}$. This is intended to identify labels that reflect the strategic interaction between the parties, rather than labels that assign the role of proxy as an attribute. This point was made recently by Walt, who, in addressing the violence in the Middle East, commented on the specific issue of control: 'Iran does not control these groups [Hezbollah and Shia militias] any more than the United States controls its own Middle East clients ${ }^{972}$.

The endorsement-enforcement framework is presented in the matrix below. The most commonly used labels, 'patron' and 'principal', on one side, and 'client' and 'pawn' on the other, show both a high ideological endorsement and a negative enforcement on control. All the four are value laden labels and translate the powerful West-East ideological 
divide: 'patron' and 'principal' show general concerns for attaining hegemony, while 'client' and 'pawn' point to the search for bipolar alignment. Their weak ability to capture accurate relational dynamic is demonstrated, for example, by the Syria-Soviet Union/Russia relationship, which even under the auspices of the superpower competition was far from being static and unidirectional. First, at the turn of the 1970s, Syria was 'wooed assiduously' by the Soviet leadership ${ }^{73}$ given its starch determination to refuse to endorse US Secretary of State William Rogers's 1970 peace initiative which had Moscow's blessing. For the USSR, Syria allowed the Soviets to check both Turkey and Israel, while providing a link to Arab nationalism. Nevertheless, both sides retained a clear understanding of existing levels of incompatibility between the two sides' strategic goals, which Foreign Minister Gromyko decisively, and repeatedly, relayed to Hafiz al-Assad ${ }^{74}$. As such, treating Syria as a mere client for the 'big power patron' implied a deterministic and compliant top down relationship that was far from accurate and that developed beyond mere clientelism. Even in the context of the ongoing Syrian civil war, the Syrian-Russian relationship posed policy dilemmas that replicated the same Cold War mentality. Following the Russian intervention in Syria, President Obama claimed 'Putin had to go into Syria not out of strength but out of weakness, because his client Mr. Assad was crumbling. ${ }^{75}$ We see here the relevance of semantics in framing policy, for Obama's client comments were as much insight into as they were defence of his vacillation over American intervention in Syria ${ }^{76}$. In this context, however, the Syria-Russia relationship has evolved as a complicated alliance in which each 
parties' goals exerted reciprocal leverage. ${ }^{77}$ If Syria's aim was regime preservation at all costs, Russia aims were threefold: to counter the domestic pressures of terrorist threats; to embed Russia in the regional economy, and to restore its status internationally by gaining the bargaining position in the Levant having demonstrated the failures of West in the region ${ }^{78}$.

[INSERT Table 1. Minimizing Terminological Reach HERE]

Second, 'principal', 'sponsor', 'surrogate', and 'satellite' relax the assumption of subordination in the proxy relationship, but still display a similarly high ideological endorsement which positions proxy wars again under the remit of Cold War interactions. Of concern are also the implications brought by 'activator', 'subordinate' and 'tool' because, despite allowing proxy wars to move beyond the Cold War debate, the labels reduce the proxy's ability to represent its interests in the overall proxy relationship by emphasising a negative endorsement of control. Recent research into the Middle East succumbed to this vision of denying agency to regional and local actors by relegating them as secondary actors in shadow wars ${ }^{79}$. This is rather problematic. First, it ignores the possibility of blowback, agency slack, or issues with moral hazard. As Cockburn put it, some actors on the ground are 'incompetent, corrupt, or simply crazed ${ }^{\prime 80}$. Second, it also ignores local third parties and their local agendas. In 2015, Hamas momentarily left the Iranian strategic orbit and began cultivating ties with Saudi Arabia, leaving Iran to shift its support to the newly emerging al Sabirin movement ${ }^{81}$. The policy debate on sponsoring rebels in Syria during 2012 and 2013 
followed a logic seeking to identify actors that had 'skin in the game already", ignoring, however, the ability of the many rebel groups not only to evade 'imposed' direction but chart their own strategic path. A clear example was the fact that many groups began working with Jabhat al-Nusra based on their own strategic considerations.

The labels become less restrictive once a joint level of low ideological endorsement, and a positive enforcement of control is reached. This is where minimising terminological reach becomes useful: the labels 'benefactor', 'agent', or 'proxy' manage to frame the constitution of a proxy relationship in a more nuances way by emphasising party agency and interaction. Hezbollah allows for the development of this point very clearly, both preand post-Cold War. Its relationship with Iran and Syria came to be talked about exclusively in terms of proxyship ${ }^{83}$, as Hezbollah moved from controlled third party under Hafez alAssad, to strategic partner under Bashar-al Assad, whilst developing almost symbiotic ties with the Iranian regime ${ }^{84}$.

Hezbollah emerged as an alternative to the perennially disenfranchised Lebanese Shia communities, which in the middle of the 1970s found a faint representation in a group called Amal, initially led by a Shia cleric, Musa Al-Sadr. The advent of the Lebanese civil war and Israel's 1982 intervention saw a spiralling of intra and inter group violent dynamics. Hezbollah presented an alternative to Amal which had already began collaborating with the Lebanese government, thus furthering Shia discontent. For Syria and Iran, Hezbollah became a vessel to channel their intrinsic hostility towards Israel and the Lebanese 
governments. As Byman put it, 'for both countries, using Hezbollah as a proxy allowed some degree of deniability, enabling them to strike at Israel ${ }^{\$ 5}$. Hezbollah translated Iranian backing into much needed organisational strength and ideological clout and benefitted from Syria's role as a conduit of weapons, logistical support, and money, as well as its ability to crack down on rivals in Lebanon. The relationships fluctuated, showing how Hezbollah should not be labelled as a mere pawn or client. As Iran failed to win decisively against Iraq, Hezbollah distanced itself from the Islamist regime, and aligned itself more with Syria whose position was determined by its own goal of overcoming international isolation and regime preservation. Hezbollah abandoned its initial goals of transforming Lebanon in fundamentally religious state, and it transitioned from a 'ragtag collection of Shiite fighters ${ }^{96}$ into a key strategic proxy actor across the Middle East, itself able to establish proxy relationships. More recently, its relationship to Hamas and the Palestinian Islamic Jihad has been portrayed in such terms, with reports of the group trying set out its very own proxy, the Return Brigades ${ }^{87}$.

Given this brief, albeit telling, example, the article attempts to bridge the need for minimizing terminological reach with that of maximising conceptual rigor, by presenting a set of labels able to harness analytical power of the endorsement-enforcement spectrum. It proposes that parties engaged in proxy wars be labelled in the following way: the party requesting indirect intervention as 'beneficiary', the party providing indirect intervention as 'proxy', and the party being acted upon through indirect intervention as 'target'. The 
changes are minor, yet significant, and are not a matter of simple stylistic choice. Given the Russian refusal to portray the Syrian situation as a civil war and its instance on labelling rebel groups as terrorists, clarity over terminology seems more important than ever.

The choice of 'beneficiary' is justified in the light of the fact that Mumford's 'benefactor' is one-dimensional: the meaning of 'benefactor' is oriented more toward the party's responsibility for the Proxy. This is also the case of Salehyan's use of 'Principal'. Using 'beneficiary' links the party proving support to the overall aims of the delegation of violence in relation to the Target, while not denying the Proxy a degree of self-orientation. The label 'Proxy' is used as it is the least connotative on the endorsement-enforcement scale in comparison with that of 'client', 'subordinate', 'pawn' or 'satellite'. Lastly, the notion of 'target' is consistent with San-Akca's emphasis on its value to strategic interaction ${ }^{88}$. This separates the notion from that of a normal proxy target which is a party that becomes a target only through proximity to the conflict. Thus, the use of 'beneficiary', 'proxy' and 'target' highlights the triadic interactions as the core of the phenomenon described by the concept of 'proxy war' in a connotation-free and more nuanced way.

\section{Maximizing Conceptual Rigor: Explaining Party Dynamics in Proxy Wars}

The terminological system presented previously helps maximise the term's rigor by shifting the focus on the interactions that form the core of the phenomenon: the triadic 
Beneficiary-Proxy-Target relationship. In doing so it invites a reconsideration of how we define and explain proxy wars. This section discusses how terminological stability translates into conceptual clarity by, firstly, proposing a working definition for proxy wars, and, secondly, carrying out a structural-relational analysis of party dynamics in proxy wars to aid the debate on causal explanations.

I define a proxy war as a violent armed interaction resulting from the polarization of competing political goals between two organised parties, a Beneficiary and a Target, in which at least one party engages the other indirectly in sustained collective violence through a third party, the Proxy. First, the definition establishes a set of core features of the phenomenon: the third party, indirect intervention, and relational interaction. Second, it allows to analytically differentiate proxy wars as acts of violence in the light of their chronic misrepresentation in conflict research. By emphasising violence, this definition reflects on proxy wars as warring events resulting from three overlapping dyads: the Beneficiary-Target dyad; the Beneficiary-Proxy dyad; and the Proxy-Target dyad. What constitutes a proxy war is the indirect projection of violence onto the Beneficiary-Target dyad via the Proxy-Target dyad through the Beneficiary-Proxy dyad.

The correlations between the three dyads, however, is something the literature has pointed out, especially with the recent work by San-Acka. Even more so, it has presented this by focusing on strategic interaction. To clarify, 'strategic interaction' refers to the correlation between one's alternatives and choices with those of other actors ${ }^{89}$. To better 
articulate our understanding of this complex relational triad, the article sketches a tentative explanation of how proxy dynamics come about. Because explanations have so far been reduced to an interest-power rationale ${ }^{90}$, strategic interaction captures the deep structures of relational interaction, and not the thin layers of actor-assigned considerations, such as risk management, power, or cost-effectiveness.

Drawing on the advantages of semantic clarity, the relationship underling by the notion of 'proxy war' can be understood as the correlation between the strategic configuration of the Beneficiary's goal towards the Target, and the Proxy's preference relative to the Beneficiary. This bridges two dimensions: the Beneficiary-Target relationship, with a focus on the Beneficiary's desired outcome/goal towards the Target; and the Proxy's willingness to distribute violence against the Target based on a preference for the Beneficiary. Because a thorough examination of the goal-preference spectrum exceeds the space of this article, goals are defined as ends to be achieved, and preferences as attitudinal or behavioural (pre)-dispositions towards a type of action or actor.

Goals structure the Beneficiary's role in the dynamic by setting a Target-related end, and preferences optimize the Proxy's position vis-a-vis the Target. This is consistent with Salehyan, Gleditsch, and Cunningham's observation that indirect intervention is conditioned by the intervener's motivation as well as their potential options for doing so. More so, it draws on Gleditsch's observations that the transnational dimensions of civil wars result not just from direct contagion, but also through actor-specific mechanisms ${ }^{91}$, and 
reiterates Salehyan's emphasis that the relationship should be understood as a variant of a strategic partnership ${ }^{92}$. It differs, however, from San-Akca's recent theorisation which presented a simultaneous, two-tiered selection mechanism: from supporting state to proxy, and from proxy to supporting state.

By emphasising the role of the Proxy's preference, the article's contribution reaffirms San-Akca's second 'selection' dynamic. It also brings the Proxy into the centre of causal explanations as an attempt to capture actor agency and the inherent variation of why it accepts delegation of violence. It is important to note that in the absence of the proposed terminological assessment, both the agency and variation of the Proxy's motivation would struggle to gain causal weight due to the implications of subordination implied by labels such as 'client', 'pawn', or 'puppet'. As such, instead of framing their participation as motived by goals, I contend that preferences are a stronger explanatory variant because, most often, the Proxy is already in a clearly defined antagonist relationship with the Target. In most cases, proxy wars unfold against the background of on-going wars where the ProxyTarget relationship is set.

The complexity of the Syrian civil war shows this accurately with the rebels receiving support already being involved in a strategic contest with the government and with each other. The United Nations' middleman in Syria, Lakhdar Brahimi, characterised the situation in Syria by noting this exact overlap, namely that the war 'is at the same time, a civil war, a sectarian war and a proxy war. ${ }^{93}$ This was made possible by regional dynamics 
which have exerted a powerful pull on the conflict: the Turkish bid for neo-Ottomanism ${ }^{94}$, the Iranian-Saudi Arabia rivalry, ${ }^{95}$ Israel's pursuit for security at a time of Iranian push for hegemony ${ }^{96}$, and a growing realisation by Qatar, the United Arab Emirates, and Saudi Arabia of the diminishing prospects of externally guaranteed security. As such, by July 2018, the Free Syrian Army (FSA) had become Turkey's proxy, the Kurds had assumed their historical proxy partnership with the United States going back the 1970s, and Iran had employed a vast network of proxy militias manned and trained by Hezbollah to transform Syria into an outpost of Iranian power. ${ }^{97}$ To see the analytical value of preference in this context, consider the example of the Kurds. In assuming the role of proxies ${ }^{98}$, the armedbranches of the various Kurdish factions across Syria acted on a manifested preference for the Unites States. The Obama administration considered the Kurds to be a trusted 'partner' to fight ISIS ${ }^{99}$, and the Trump administration continued cooperation with them as 'foreign partners ${ }^{100}$. In doing so, the Kurds exchanged strategic utility for political recognition and legitimization which has been crucial in maintaining a supposed distance from the Kurdistan Workers' Party (PKK) and managing the Turkish opposition to their territorial claims. ${ }^{101}$ For its part, Turkey co-opted factions of the Iraqi Kurds as a proxy counterweight to the emerging Rojava territorial formation at its border with Syria ${ }^{102}$.

The example of the Kurds also shows that preference does not imply proxies do not seek specific aims. In fact, preference presents an opportunity to differentiate between purely selfish reasons and more complex strategic associations. The first category would 
reference Tamm's recent insights into the role of survival and financial gain in African civil wars experiencing external support ${ }^{103}$. The second references the pull the issue of ethnic or religion kin has in the provision of support ${ }^{104}$, and is best exemplified by Hezbollah and Iran. Their relationship draws on the distinct power of the doctrine of velayat-e faqih, or the guardianship of the jurist in the person of the Ayatollah. As previously mentioned, the relationship has been anything but linear. However, velayat-e faqit is a marker of distinct preference which has allowed the group to develop into a legitimate political party, and, in this process, to outgrow its relationship with Syria. Here we observe again the need for clear terminologies and its impact on definition and explanation: having operated under the assumption that Hezbollah was merely a Syrian or Iranian 'pawn', would have reduced our ability to explain its role and links in the region. Its current involvement in the Syrian civil war is strategically relevant to the group itself. It is not strategically coerced by its current/former 'mentor', but rather the result of a preference towards the Ayatollah's strategic vision for the Middle East in which Syria and Lebanon are key for maintaining a line of defence against Israel and Saudi Arabia.

If preferences help to account for Proxy choices, by focusing on the Beneficiary's goals, we can better integrate the literature's typological efforts to understand the rationale for delegating violence, ranging from influence, destabilisation, or retaliation ${ }^{105}$. Despite being acknowledged by San-Akca, it is not included in her selection theory which only looks at 'various paths to collaboration between states and rebel groups" ${ }^{106}$. As such, this article 
adds the relationship between the supporting state and its desired target as an additional key insight making it a significant contribution resulting from the terminological assessment and its emphasis on the recognition of the Target as integral to the proxy war process. This shifts the current explanation of the decision to delegate violence from focusing on the Proxy to focusing on the Target.

The reason is that the historical evolution of proxy wars has shown how little consideration supporting states have for proxies. The clearest support for this statement was offered by the former US Secretary of State, Condoleezza Rice in her striking admission in 2005 of America's long record of sponsoring tyrants for more than six decades $^{107}$. A careful reading of US and Soviet Cold War proxy wars shows how little preference mattered for the Beneficiary. The US proxy war pattern is quite striking: in the Philippines it supported the upper class ilustrados; in Afghanistan, the mujahedeen set the scene for the twenty-first century's biggest security challenge; and in Latin America, thuggish rebel groups made Nixon realise that, as Kissinger put it, "the imperative of geopolitical equilibrium overrode the demands of ideological purity" ${ }^{\prime \prime 2}$.

The current developments of proxy wars in the Middle East underscore the supporting states' focus on the target, and not on the Proxy. In Gaza, as Hamas attempted a strategic relocation in the Saudi camp, Iran wasted no time to start channelling funding to the Palestinian Islamic Jihad or the al Sabirin group as proxies against Israel. In its relationship to Hezbollah, Syria sought to regain control over Lebanon and to set up a 
buffer against Israel. Its focus on goals, rather than preference, explains the mechanical relationship Hafez al-Assad developed with Hezbollah which the Alawite attempted to rein by pitting other local actors against it whenever the group acted in its own interests ${ }^{109}$. As discussed above, the Syrian civil war has seen staggering regional intervention all informed by individual goals, and not commitments to rebel causes.

Turkey's interest in supporting the FSA placed Syria second to the existential threat the PKK pose. Saudi Arab willingness and quick reaction to rebel needs is linked to Iranian rivalry rather than to the prospects of a democratic country. ${ }^{110}$ Similarly, Iran has focused on Syria as the collapse of the regime would leave Iran exposed in its confrontation with regional enemies, directly affect its ability to provide support to Hezbollah, and thwart the country's naval ambitions ${ }^{111}$. Finally, while Russia proceeded with a direct military intervention aimed at projecting a long-sought power-broker status at the international level, the United States oscillated on the issue of rebel support, and after initial reluctance, opted for a covert operation centred on the FSA and the armed wings of the Kurds. The decision involved a process of vetting which could be understood as preference, but as Clinton explained, it was the fear of blowback and the publication of a CIA report on the long history of failed proxy wars that informed the decision not to provide support ${ }^{112}$. The reliance on Kurdish forces ultimately provided what Bernard-Henri Lévy's called 'no sorrier spectacle ${ }^{9113}$, and is aptly explained by the notion of Beneficiary goal. Focused on developing a counterinsurgency strategy to fight ISIS, the US divorced this issue from the 
context in which it emerged. As such, it enlisted the Kurds in an effort considered both inconsistent and highly conditional, but accepted, as explained, through a high preference for the United States. ${ }^{14}$ With the Trump administration now committed to withdrawing from Syria, the future of the civil war is left to the Turkey-Iranian-Russian triumvirate. However, any plan of moving forward must consider the wider regional implications given the pressures of a counterpoise from Saudi Arabia, Egypt, and the United Arab Emirates, all employing their own proxies.

The Middle Eastern cauldron of proxy wars shows how the goal-preference heuristic presents the problem as constitutive of heterarchical relationships, and not hierarchical ones. In doing so it removes subordination and compliance, restoring much needed internal coherence to the idea of 'proxy war'. It provides a clearer sense of the how the dynamics between parties involved in proxy wars come about, allowing future research to turn to explaining other issues such as the conditions that make it more likely to take shape, and, most importantly, its consequences.

\section{Conclusion}


When Coker wondered about the role of language in political concepts he asked a simple question, 'What's in a name?'. His answer was as short and relevant as the question itself: 'Plenty' ${ }^{115}$. The advantage of this discussion is that it linked two systems often ignored in relation to security matters: the terminological one and the conceptual one. This analysis of proxy wars deconstructed a long-standing misunderstanding in the study of delegation of violence, namely its messy vernacular and its effects on the properties of the concept it describes. The overall aim was not to add more to exciting jargon, but to add a muchneeded layer of reflection on how we conceptualise and theorise proxy wars as a contemporary security challenge.

First, the discussion evaluated the terminological roster of labels used to characterise the parties engaged in proxy wars. A focus on the proxy war lexicon addressed the fact that process of naming and selecting terminology imports substantive value to the concept itself, to the framework developed to assess it, and to the range of solutions we seek to answer it. ${ }^{116}$ The aim was to demonstrate that lack of semantic precision influences the overall concept, its definition, and its utility. To do so, the article developed the endorsement-enforcement matrix from the assumption that 'political concepts are doubly related to a socio-linguistical context from which they emanate and which they seek to interpret and shape'. ${ }^{117}$ Applied to the literature on proxy war and external supposed it showed the inadequacy of the existing lexicon. By making the case for the use of 'beneficiary', 'proxy', and 'target', the article paved the way for further theory building able 
to advance the debate and answer relevant policy questions. The need for such an analysis was nowhere more evident than in the remarks of former British Foreign Secretary, Boris Johnson, who accused Iran and Saudi Arabia of 'puppeteering and playing proxy wars" ${ }^{118}$, creating a cabinet impasse that jeopardised the British strategy towards the Syrian civil war.

Johnson's remarks show that language is a powerful tool with a tremendously transformative power, and the analysis used the endorsement-enforcement matrix to show how choices over labels in proxy wars became choices over the definition and explanation of the phenomenon itself. The article addressed this problem by drawing a theoretical framework that added the goal-preference heuristic to the current discussion on causality. This shifted the discussion to the essence of the matter, the triadic strategic interaction. More importantly, in introducing the preference-goal heuristic, the article offers a vantage point from which future research can develop. The article's empirical backbone was the complex set of Middle Eastern proxy wars, and this showed how varied the extent of waging proxy wars can be. As John Bew put it, 'much dry tinder remains in these overlapping proxy wars ${ }^{, 19}$ with these conflicts engulfing local, sub-national, national, regional, and international actors. Nevertheless, the structural-relational analysis of proxy war party dynamics is a step forward because it helps open a more in-depth inquiry into proxy wars. One such potential avenue is the comparative assessment of why states wage proxy wars starting from the goalpreference heuristic. By developing a range of goals and by setting up degrees of preference, future research can set forth a more comprehensive typology of logics of violence behind 
waging proxy wars. This will no doubt move both research and policy closer to developing strategies to confront and counter the messy military and political realities of proxy wars.

Table 1. Minimizing Terminological Reach 


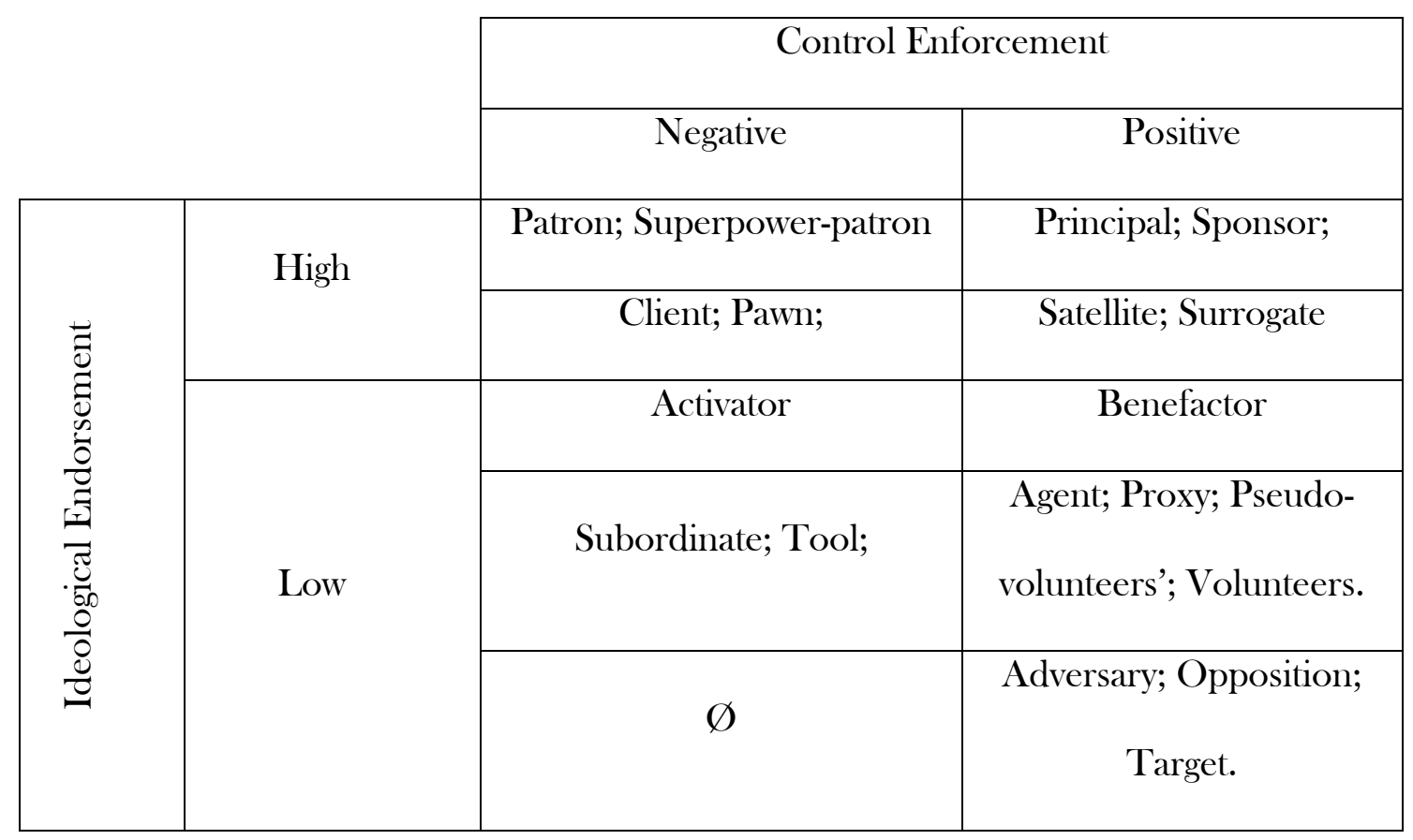

Notes 
'John Gerring, 'What Makes a Concept Good? A Criterial Framework for Understanding Concept Formation in the Social Sciences', Polity, 31(2), 1999, pp. 357-93.

${ }^{2}$ Ken Booth, 'Security and Emancipation', Review of International Studies, 17(4), 1991, pp. 313-26; David A. Baldwin, 'The Concept of Security', Review of International Studies, 23(1), 1997, pp. 5-26; Jef Huysmans, 'Security! What Do You Mean?', European Journal of International Relations, 4(3), 1998, pp. 226-55.

${ }^{3}$ Leonard Weinberg, Ami Pedahzur, and Sivan Hirsch-Hoefler, 'The Challenges of Conceptualizing Terrorism', Terrorism and Political Violence, 16(4), 2004, pp. 777-94; Anthony Richards, 'Conceptualizing Terrorism', Studies in Conflict \& Terrorism, 37 (3), 2014, pp. 213-36.

${ }^{4}$ Nicholas Sambanis, 'What Is Civil War? Conceptual and Empirical Complexities of an Operational Definition', The Journal of Conflict Resolution, 48(6), 2004, pp. 814-58.

${ }^{5}$ David Armitage, Civil Wars. A History in Ideas (Yale: Yale University Press, 2017).

${ }^{6}$ Harvey Starr, 'Cumulation from Proper Specification: Theory, Logic, Research Design, and 'Nice' Laws', Conflict Management and Peace Science, 22(4), 2005, pp. 353-63.

${ }^{7}$ Seyom Brown, 'Purposes and Pitfalls of War by Proxy: A Systemic Analysis', Small Wars \& Insurgencies, $27(3), 2016$, p. 243.

${ }^{8}$ Geraint Hughes, My Enemy's Enemy: Proxy Warfare in International Politics (Eastbourne: Sussex Academic Press, 2012); Andrew Mumford, Proxy Warfare (Cambridge: Polity, 2013). For a general discussion on the war-warfare dichotomy, see 
Stathis N. Kalyvas, 'Warfare in Civil Wars', in Isabelle Duyvesteyn and Jan Angstrom (eds.), Rethinking the Nature of War (Abingdon: Frank Cass, 2005), pp. 88-04.

${ }^{9}$ Hughes, My Enemy’s Enemy, Mumford, Proxy Warfare; Vladimir Rauta and Andrew Mumford, 'Proxy Wars and the Contemporary Security Environment', in Robert Dover, Huw Dylan, and Michael S. Goodman (eds.), The Palgrave Handbook of Security, Risk and Intelligence (London: Palgrave Macmillan, 2017), pp. 99-116.

${ }^{10}$ Idean Salehyan, Kristian Skrede Gleditsch, and David E. Cunningham, 'Explaining External Support for Insurgent Groups', International Organisation, 65(4), 2011, pp. 70944 .

${ }^{11}$ Belgin San-Akca, States in Disguise: Causes of State Support for Rebel Groups (Oxford: Oxford University Press, 2016), pp. 24-25.

${ }^{12}$ Henning Tamm, 'The Origins of Transnational Alliances: Rulers, Rebels, and Political Survival in the Congo Wars', International Security, 41(1), 2016, pp. 147-81.

${ }^{13}$ Mumford, Proxy Warfare, p. 11.

${ }^{14}$ David H. Ucko and Thomas A. Marks, 'Violence in Context: Mapping the Strategies and Operational Art of Irregular Warfare', Contemporary Security Policy, 39(2), 2018, pp. 20633.

${ }^{15}$ Ucko and Marks, 'Violence in Context'; 
${ }^{16}$ Thomas Waldman, 'Vicarious Warfare: The Counterproductive Consequences of Modern American Military Practice', Contemporary Security Policy, 39(2), 2018, pp. 18105.

${ }^{17}$ Karin Marie Fierke, 'Links across the Abyss: Language and Logic in International Relations', International Studies Quarterly, 46(3), 2002, pp. 331-54.

18 Felix Berenskoetter, 'Approaches to Concept Analysis', Millennium: Journal of International Studies, 45(2), 2017, pp. 151-73.

${ }^{19}$ Michael V. Bhatia, 'Fighting Words: Naming Terrorists, Bandits, Rebels and Other Violent Actors', Third World Quarterly, 26(1), 2005, pp. 5-22.

${ }^{20}$ Berenskoetter, 'Approaches to Concept Analysis', p. 157.

${ }^{21}$ 'Obama's Last Press Conference: Full Transcript and Video', The New York Times, 18 January 2017, https://www.nytimes.com/2017/01/18/us/politics/obama-final-pressconference.html?mtrref=www.google.co.uk (18 February 2018).

${ }^{22}$ Adam Taylor, 'Behind Biden's Gaffe Lie Real Concerns about Allies' Role in Rise of the Islamic State', The Washington Post, 6 October 2014, https://www.washingtonpost.com/news/worldviews/wp/2014/10/06/behind-bidens-gaffe$\underline{\text { some-legitimate-concerns-about-americas-middle-east-allies/?utm_term=.4ebbc5f94162 }}$ (18 February 2018).

${ }^{23}$ Sibylle Scheipers, 'Auxiliaries at War in the Middle East', Survival, 57(4), 2015, pp. 12138. 
${ }^{24}$ Nathan Canestraro, 'Toward a Practitioner-Centric Definition of Civil War', Civil Wars, 18(3), 2016 pp. 359-77.

${ }^{25}$ Hillary Rodham Clinton, Hard Choices (London: Simon \& Schuster, 2014), p. 389.

${ }^{26}$ White Hour Office of the Press Secretary, Press Conference by the President, 16 December 2016, $\quad$ https://obamawhitehouse.archives.gov/the-pressoffice/2016/12/16/press-conference-president (17 February 2018).

${ }^{27}$ Odd Arne Westad, The Global Cold War. Third World Interventions and the Making of Our Times (Cambridge: Cambridge Universe Press, 2007).

${ }^{28}$ Gregory F. Treverton, Covert Action. The Limits of Intervention in the Postwar World (New York: Basic Books Inc., 1987).

${ }^{29}$ Daniel L. Byman, Peter Chalk, Bruce Hoffman, William Rosenau, and David Brannan, Trends in Outside Support for Insurgent Movements (California: RAND, 2001); Kristian Skrede Gleditsch, 'Transnational Dimensions of Civil War', Journal of Peace Research, 44(3), 2007, pp. 293-09; Idean Salehyan, Rebels without Borders: Transnational Insurgencies in World Politics (Ithaca and London: Cornell University Press, 2009); Idean Salehyan, 'The Delegation of War to Rebel Organisations', Journal of Conflict Resolution, 54(3), 2010, pp. 493-15; Navin A. Bapat, 'Understanding State Sponsorship of Militant Groups', British Journal of Political Science, 42(1), 2011, pp. 1-29; Salehyan, Gleditsch, and Cunningham, 'Explaining External Support'; San-Akca, States in Disguise. 
${ }^{30}$ Henning Tamm, 'Rebel Leaders, Internal Rivals, and External Resources: How State Sponsors Affect Insurgent Cohesion', International Studies Quarterly, 60(4), 2016, pp. 599-610.

${ }^{31}$ Paul Staniland, 'Armed Groups and Militarised Elections', International Studies Quarterly, 59(4), 2015, pp. 694-05;

${ }^{32}$ Niklas Karlén, 'Turning off the Taps: The Termination of State Sponsorship', Terrorism and Political Violence, Online 2018. https://doi.org/10.1080/09546553.2017.1282861 (21 July 2018).

${ }^{33}$ Kristine Eck, 'Repression by Proxy: How Military Purges and Insurgency Impact the Delegation of Coercion', Journal of Conflict Resolution, 59(5), 2015, pp. 924-46.

${ }^{34}$ Dara Kay Cohen and Ragnhild Nordås, 'Do States Delegate Shameful Violence to Militias? Patterns of Sexual Violence in Recent Armed Conflicts', Journal of Conflict Resolution, 59(5), 2015, pp. 877-98.

${ }^{35}$ Corinna Jentzsch, Stathis N. Kalyvas, and Livia Isabella Schubiger, 'Militias in Civil Wars', Journal of Conflict Resolution, 59(5), 2015, pp. 755-91; Sabine C. Carey, Michael P. Colaresi, and Neil J. Mitchell, 'Governments, Informal Links to Militias, and Accountability', Journal of Conflict Resolution, 59(5), 2015, pp. 850-76; ; Paul Staniland, 'Militias, Ideology, and the State', Journal of Conflict Resolution, 59(5), 2015, pp. 770-93; Vladimir Rauta, 'Proxy Agents, Auxiliary Forces, and Sovereign Defection: Assessing the 
Outcomes of Using Non-State Actors in Civil Conflicts', Southeast European and Black Sea Studies, 16(1), 2016, pp. 91-11.

${ }^{36}$ Mumford, Proxy Warfare, p. 1.

${ }^{37}$ W. B. Gallie, 'Essentially Contested Concepts', Proceedings of the Aristotelian Society, 56, 1955 - 1956, pp. 167-98.

${ }^{38}$ Hughes, My Enemy's Enemy, p. 11.

${ }^{39}$ Salehyan, Rebels without Borders, p. 53.

${ }^{40}$ Bertil Dunér, 'Proxy Intervention in Civil War', Journal of Peace Research, 18(4), 1981, pp. 353-61; Yaacov Bar-Siman Tov, 'The Strategy of War by Proxy', Cooperation and Conflict, 19(4), 1984, pp. 263-73.

${ }^{41}$ Christopher Lamb, 'The Nature of Proxy Warfare', in William J. Taylor Jr. and Steven A. Maaranen (eds.) The Future of Conflict, (Lexington: Lexington Books, 1982), pp. 169194.

${ }^{42}$ Lamb, 'The Nature of Proxy Warfare', p. 171.

${ }^{43}$ Paul Staniland, 'Militias, Ideology, and the State'.

${ }^{4}$ Bar-Siman Tov, 'The Strategy of War by Proxy', p. 266.

${ }^{45}$ Mumford, Proxy Warfare, p. 11.

${ }^{46}$ Janice Gross Stein, 'Proxy Wars: How Superpowers End Them: The Diplomacy of War Termination in the Middle East', International Journal, 35(3), 1980, pp. 478-19; Lamb, 'The Nature of Proxy Warfare', p. 169; Bar-Siman Tov, 'The Strategy of War by Proxy', 
p. 269; Eck, 'Repression by Proxy', p. 927; Niklas Karlén, 'The Legacy of Foreign Patrons. External State Support and Conflict Recurrence', Journal of Peace Research, 2017, 54(4), pp. 499-512.

${ }^{47}$ Dunér, 'Proxy Intervention in Civil War', p. 356; Chris Loveman, 'Assessing the Phenomenon of Proxy Intervention', Conflict, Security and Development, 2(3), 2002, pp. 29-48; San-Akca, States in Disguise, p. 10.

${ }^{48}$ Gross Stein, 'Proxy Wars', p. 481.

${ }^{49}$ Bapat, 'Understanding State Sponsorship', p. 2; Hughes, My Enemy's Enemy, p. 7; Tamm, 'Rebel Leaders', p. 599.

${ }^{50}$ Gross Stein, 'Proxy Wars', p. 478; Dunér, 'Proxy Intervention in Civil War', p. 354; Philip Towle, 'The Strategy of War by Proxy', The RUSIJournal, 126(1), 1981, pp. 21-26; Lamb, 'The Nature of Proxy Warfare', p. 1982: 175; Bar-Siman Tov, 'The Strategy of War by Proxy', p. 269; Eck, 'Repression by Proxy', p. 927.

${ }^{51}$ Gross Stein, 'Proxy Wars', p. 483.

${ }^{52}$ Gross Stein, 'Proxy Wars', p. 481; Dunér, 'Proxy Intervention in Civil War', p. 354; Lamb, 'The Nature of Proxy Warfare', p. 169; Loveman, 'Assessing', p. 32; Geraint Hughes and Christian Tripodi, 'Anatomy of a Surrogate: Historical Precedents and Implications for Contemporary Counter-insurgency and Counter-terrorism', Small Wars \& Insurgencies, 20(1), 2009, pp. 1-35; Mumford, Proxy Warfare, p. 11; Eck, 'Repression by Proxy', p. 925; Paul Staniland, ‘Armed Groups and Militarised Elections’, p. 697. 
${ }^{53}$ Towle, 'The Strategy of War by Proxy', p. 22.

${ }^{54}$ Dunér, 'Proxy Intervention in Civil War', p. 354.

${ }^{55}$ David F. Ronfeldt, Superclients and Superpowers; Cuba: Soviet Union/Iran: United States (Santa Monica: RAND, 1978), p. 1; Dunér, 'Proxy Intervention in Civil War', p. 354

${ }^{56}$ Bruce D. Porter, The USSR in Third World Conflicts: Soviet Arms and Diplomacy in Local Wars 1945-1980 (Cambridge: Cambridge University Press, 1984), p. 55.

${ }^{57}$ Lamb, 'The Nature of Proxy Warfare', p. 171; Hughes and Tripodi, 'Anatomy of a Surrogate', p. 3; Andreas Krieg, 'Externalizing the Burden of War: the Obama Doctrine and US Foreign Policy in the Middle East', International Affairs, 91(1), 2016, pp. 97-13.

${ }^{58}$ Ronfeldt, Superclients and Superpowers, p. 1.

${ }^{59}$ Dunér, 'Proxy Intervention in Civil War', p. 354.

${ }^{60}$ Dunér, 'Proxy Intervention in Civil War', p. 354-355; Towle, 'The Strategy of War by Proxy', p. 21.

${ }^{61}$ Gross Stein, 'Proxy Wars', p. 478; Bar-Siman Tov, 'The Strategy of War by Proxy', p. 263.

${ }^{62}$ Lamb, 'The Nature of Proxy Warfare', p. 185).

${ }^{63}$ Hughes, My Enemy's Enemy, p. 5.

${ }^{64}$ Bar-Siman Tov, 'The Strategy of War by Proxy', p. 263. 
${ }^{65}$ Miriam R. Estrin and Jeremy Shapiro, 'The Proxy War Problem in Syria', Foreign Policy, 4 February 2014, http://foreignpolicy.com/2014/02/04/the-proxy-war-problem-in-syria/ (15 February 2018).

${ }^{66}$ Michael Freeden, 'Political Concepts and Ideological Morphology', The Journal of Political Philosophy, 2(2), 1994 pp. 140-64

${ }^{67}$ Stathis N. Kalyvas and Laia Balcells, 'International System and Technologies of Rebellion: How the End of the Cold War Shaped Internal Conflict', American Political Science Review, 104(3), 2010, p. 420;

${ }^{68}$ Tamm, 'The Origins of Transnational Alliances', p. 152.

${ }^{69}$ San-Akca, States in Disguise, p. 2.

${ }^{70}$ Freeden, 'Political Concepts', p. 158.

${ }^{71}$ Staniland, 'Militias, Ideology, and the State', p. 772.

${ }^{72}$ Stephen M. Walt, 'The Islamic Republic of Hysteria', Foreign Policy, 16 January 2018, http:/foreignpolicy.com/2018/01/16/the-islamic-republic-of-hysteria-iran-middle-east-

trump/ (15 February 2018).

${ }^{73}$ Dina Rome Spechler, 'The Politics of Intervention: The Soviet Union and the Crisis in Lebanon', Studies in Comparative Communism, 20(2), 1987, p. 121.

${ }^{74}$ Spechler, 'The Politics of Intervention', p. 12.

${ }^{75}$ Peter Baker and Neil MacFarquhar, 'Obama Sees Russia Failing in Syria Effort', The

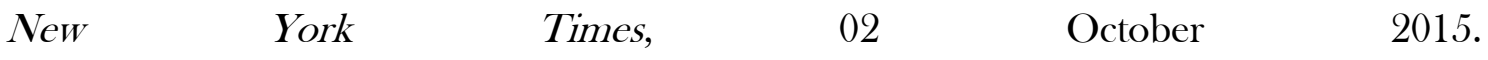


July 2018).

${ }^{76}$ Fawaz A. Gerges, Obama and the Middle East. The End of America's Moment? (London: Palgrave Macmillan, 2012); Krieg, 'Externalizing the Burden of war: the Obama Doctrine and US Foreign Policy in the Middle East'.

${ }^{77}$ Neil MacFarquhar, 'Russia's Greatest Problem in Syria: Its Ally, President Assad', The $\begin{array}{lllll}\text { New } & \text { York } & \text { Times, } & 08 & \text { March }\end{array}$ https://www.nytimes.com/2018/03/08/world/europe/russia-syria-assad.html (23 July 2018).

${ }^{78}$ Derek Averre and Lance Davies, 'Russia, Humanitarian Intervention, and the Responsibility to Protest: The Case of Syria', International Affairs, 91(4), 2015, pp. 813-34; Christopher Phillips, The Battle for Syria. International Rivalry in the New Middle East (New Haven and London: Yale University Press, 2016); Angela Stent, 'Putin's Power Play in Syria, Foreign Affairs, 14 December 2015, https://www.foreignaffairs.com/articles/united-states/2015-12-14/putins-power-plav-syria (23 July 2018).

${ }^{79}$ Christopher Davidson, Shadow Wars: The Secret Struggle for the Middle East (London: One World, 2017).

${ }^{80}$ Patrick Cockburn, 'Just Who Has Been Killing Iran's Nuclear Acientists?', The Independent, 5 October 2013, http://www.independent.co.uk/voices/comment/just-whohas-been-killing-irans-nuclear-scientists-8861232.html (15 February 2018). 
${ }^{81}$ Ehud Yaari, 'Replacing Hamas. Iran's New Proxy Militias in Gaza, Foreign Affairs, 20 September 2015, https://www.foreignaffairs.com/articles/palestinian-authority/2015-0928/replacing-hamas (15 February 2018).

${ }^{82}$ Daniel Byman, 'Six Bad Options for Syria', The Washington Quarterly, 38(4), 2016, p. 178.

${ }^{83}$ Brendan Sozer, 'Development of Proxy Relationships: A Case Study of the Lebanese Civil War’, Small Wars \& Insurgencies, 27(4), 2016, pp. 636-658.

${ }^{84}$ Emile El-Hokayem, 'Hezbollah and Syria: Outgrowing the Proxy Relationship', The Washington Quarterly, 30(2), 2007, pp. 35-52.

${ }^{85}$ Daniel Byman, 'Understanding Proto-Insurgencies', Journal of Strategic Studies, 31 (2), 2008, 165-00.

${ }^{86}$ Byman, 'Understanding Proto-Insurgencies', p. 171.

${ }^{87}$ Ben Hubbard, 'Iran Out to Remake Mideast with Arab Enforcer', The New York Times, 27 August 2017, https:/www.nytimes.com/2017/08/27/world/middleeast/hezbollah-iransyria-israel-lebanon.html (14 February 2018).

${ }^{88}$ San-Akca, States in Disguise: Causes of State Support for Rebel Groups, p. 3.

${ }^{89}$ David A. Lake and Robert Powell (eds.) Strategic Choice and International Relations, (Princeton: Princeton University Press, 1993), p. 3.

${ }^{90}$ Mumford, Proxy Warfare.

${ }^{91}$ Gleditsch, ‘Transnational Dimensions of Civil War', p. 295. 
${ }^{92}$ Salehyan, 'The Delegation of War to Rebel Organisations'.

${ }_{93}$ 'Interview with Lakhdar Brahimi', Politically Speaking, 22 August 2013. https://theelders.org/article/syria-civil-sectarian-and-proxy-war (22 July 2018).

${ }^{94}$ Jonathan Schanzer and Merve Tahiroglu, 'Ankara’s Failure: How Turkey Lost the Arab $\begin{array}{lllll}\text { Spring', } & \text { Foreign } & \text { Affairs, } & 25 & \text { January }\end{array}$ https://www.foreignaffairs.com/articles/turkey/2016-01-25/ankaras-failure (23 July 2018).

${ }^{95}$ Simon Mabon, Saudi Arabia and Iran. Power and Rivalry in the Middle East (London: I. B. Tauris, 2013).

${ }^{96}$ Dina Esfandiary and Ariane Tabatabai, 'Iran’s ISIS Policy', International Affairs, 91(1), 2015, pp. 1-15.

${ }^{97}$ John Jenkins, 'The War between the Middle East Wars', New Statesman, 11-17 May 2018, pp. 23-26.

${ }^{98}$ Joost Hiltermann and Maria Fantappie, 'Twilight of the Kurds', Foreign Policy, 16 January 2018， $\quad$ http://foreignpolicy.com/2018/01/16/twilight-of-the-kurds-iraq-syriakurdistan/ (13 February 2018).

${ }^{99}$ Fred Kaplan, 'Obama's Way. The President in Practice', Foreign Affairs, JanuaryFebruary 2015, https://www.foreignaffairs.com/articles/2015-12-07/obamas-way February 2018)

${ }^{100}$ Eric Schmitt, 'Detained ISIS Fighters Pose Risk', The New York Time, 26 January 2018, https:/www.nytimes.com/2018/01/24/world/middleeast/isis-syria-militants- 
kurds.html?mtrref=www.google.co.uk\&gwh=E09F2D2C745403E247A9E130871E6116\& gwt=pay (13 February 2018).

${ }^{101}$ Rod Nordland, 'Syrian Kurds: U.S. Allies, but Followers of Leader Jailed as Terrorist', The New York Times, 10 March 2018, https://www.nytimes.com/2018/03/10/world/middleeast/syria-kurds-turkev-rojavaabdullah-ocalan.html (23 July 2018).

${ }^{102}$ Rod Thornton, 'Problems with the Kurds as Proxies against Islamic State: Insights from the Siege of Kobane', Small Wars \& Insurgencies, 26(6), 2015, pp. 865-85.

${ }^{103}$ Tamm, 'The Origins of Transnational Alliances'.

${ }^{104}$ Lars-Erik Cederman Kristian Skrede Gleditsch, Idean Salehyan, and Julian Wucherpfenning, 'Transborder Ethnic Kin and Civil War', International Organisation, 67(2), 2013, pp. 389-10.

${ }^{105}$ Byman et. al., Trends in Outside Support for Insurgent Movements.

${ }^{106}$ San-Akca, States in Disguise, p. 3.

${ }^{107}$ Condoleezza Rice, 'Remarks at the American University in Cairo', 20 June 2005, https://2001-2009.state.gov/secretary/rm/2005/48328.htm (17 February 2018).

${ }^{108}$ Henry Kissinger, World Order (London: Penguin, 2015), p. 305.

${ }^{109}$ Marc R. Devore and Armin B. Stähli, 'Explaining Hezbollah's Effectiveness: Internal and External Determinants of the Rise of Violent Non-State Actors', Terrorism and Political Violence, 27(2), 2015, pp. 331-57. 
${ }^{110}$ Marc Lynch, The New Arab Wars. Uprisings and Anarchy in the Middle East (New York: Public Affairs, 2017).

${ }^{111}$ Yoel Guzansky, 'Iran’s Growing Naval Ambitions', Foreign Affairs, 1 January 2017, https://www.foreignaffairs.com/articles/iran/2017-01-(01/irans-growing-naval-ambitions (18 February 2018).

${ }^{112}$ Clinton, Hard Choices, p. 392.

${ }^{113}$ Bernard-Henri Levy, 'The US will Rue its Betrayal of the Kurds', The New Statesman, 10-16 November 2017, https:/www.newstatesman.com/world/2017/11/us-will-rue-itsbetrayal-kurds (13 February 2018).

${ }^{114}$ Jenkins, 'The War between the Middle East Wars', p. 25.

${ }^{115}$ Christopher Coker, War in an Age of Risk (London: Polity, 2009), p. 62.

${ }^{116}$ Armitage, Civil Wars. A History in Ideas, p. 13,

${ }^{117}$ Freeden, 'Political Concepts', p. 141.

${ }^{118}$ 'Boris Johnson accuses Saudi Arabia of playing proxy wars', BBC, 08 December 2016, http://www.bbc.co.uk/news/uk-politics-38245902 (18 February 2018).

${ }^{119}$ John Bew, 'Trump's Mission Accomplished Boats Confirm the West has no Serious Strategy for Syria', New Statesmen, 22 April 2018, https://www.newstatesman.com/world/middle-east/2018/04/trump-s-missionaccomplished-boasts-confirm-west-has-no-serious-strategy (23 July 2018). 